\title{
Comparative Histological Observation of Liver Tissue Before and After Reproduction in Male and Female Frogs (Pelophylax ridibundus)
}

\author{
Ahmet Alkaya $^{1^{*}}$ (1), Hülya Şereflişan ${ }^{1}$ (D) \\ Cite this article as: Alkaya, A., \& Sereflisan, H. (2019). Comparative Histological Observation of Liver Tissue Before and After Reproduction in Male \\ and Female Frogs (Pelophylax ridibundus). Aquatic Sciences and Engineering, 34(2), 46-50.
}

ORCID IDs of the authors:

A.A. 0000-0003-2117-7799,

H.Ş. 0000-0002-2510-3714

'Iskenderun Technical University, Marine Sciences and Technology

Faculty, Iskenderun, Hatay, Turkey

Submitted:

07.03.2019

Revision Requested

08.05.2019

Last Revision Received

14.05.2019

Accepted:

21.05.2019

Online published:

28.06.2019

Correspondence:

Ahmet Alkaya

E-mail:

ahmtalkaya674@gmail.com

(C) Copyright 2019 by Aquatic

Sciences and Engineering

Available online at

https://dergipark.org.tr/ase

\begin{abstract}
Histomorphological structure of the liver of Ranidae species during the reproduction period contribute significantly to the production rate in the frog culture studies. In this study, the cytoplasmic status of hepatocytes, lipid and melanin pigment in liver parenchyma of adult male and female Pelophylax ridibundus (Pallas, 1771) were investigated before and after reproduction. For histological studies, adult frogs were collected from nature and placed in production ponds to examine the reproduction process. In this study, twenty four breeding male frogs, with average weight $36.63 \pm 12.84 \mathrm{~g}$ and length $69.29 \pm 9.15 \mathrm{~mm}$, and twenty four breeding females with average weight and length of $56.61 \pm 19.59 \mathrm{~g}$ and $79.54 \pm 7.07 \mathrm{~mm}$ were used. Samples from the liver tissue of frog were taken in 2015 during (March) and after reproduction (June) period. Histologically pictures of liver parenchyma were taken from the as homogeneous fields as possible. Before the reproduction, it was found that the liver parenchyma of the female frogs were cytoplasmically intense, with a low amount of melanin pigment and lipid droplets. Similarly, male frogs liver parenchyma and hepatocytes were found to be cytoplasmically intense, containing a low amount of melanin pigment and lipid droplets. Both female and male frogs completed the reproduction in April and May. After reproduction period, a great amount of melanin pigment in the liver parenchyma was observed and the cytoplasmic density of the hepatocytes decreased. As a result, cytoplasmic decrease in hepatocytes, structural changes and increase in melanin pigments supports the idea that glycogen and lipids stored in the liver parenchyma are used for reproduction.
\end{abstract}

Keywords: Pelophylax ridibundus, Ranidae, liver tissue, hepatocyte, histology, reproduction

\section{INTRODUCTION}

Examining the histological changes is one of the important research areas of biology and aquaculture laboratories (Wester \& Canton, 1991). In addition, knowing the histophysiological structure of Ranidae species which are economically valuable and commonly cultivated contributes significantly to the reproduction rate of this species (Bambozzi et al., 2004; Arauco, De Stefani, Nakaghi \& Oliveira-Bahia, 2007). Before and after reproduction differences in liver or gonads and alterations caused by environmental effects can be followed by histological studies in amphibians (Gernhofer, Pawet, Schramm, Müller \& Triebskorn, 2001). The liver plays a number of indispensible functions in many body physiological processes such as the digestion of nutrients from other parts of the body and also a storage area for the nutrients. Therefore, it is perfect organ of a key to understand the health and nutritional status of the animals (Akiyoshi \& Inoue, 2012). On the other hand, liver tissue is a very good reflector of health management caused diseases and infections in food processing and zootechnics (Hipolito, Leme \& Bach, 2001; Hipolito, Martins \& Bach, 2004). However, information about the 
normal and abnormal functions of the amphibian liver is still limited. Thus, most liver disorders are known only by a retrospective diagnosis or autopsy (Crawsha \& Weinkle, 2000).

Chen et al. (2011) noted in Rana chensinensis the increase in glycogen and lipid reserves before the reproduction and hibernation period and reported that the increase in glycogen and lipid reserves between reproduction and hibernation period altered depending on reproductive strategy. The increase in melanin pigment in liver parenchyma is inversely related to glycogen and lipid concentration. It is thought that glycogen, lipid and other substances are stored in the liver for the energy needed in the reproductive period. Furthermore, these substances are used in the initial formation of egg-sperm as well as energy-requiring activities such as cell division and mating (Cadeddu \& Castellano 2012; Cayuela et al., 2014; Mentino, Mastrodonato, Rossi \& Scillitani, 2014).

Mentino et al. (2017) discovered the seasonal changes in glycogen, lipid and melanin pigment in the liver of frog (Pelophylax esculentus). They found that melanin pigment in the liver tissue reach its maximum value during May and June which could be related with the reproductive activities. Asisi (1991) reported the degenerative changes in some liver hepatocytes after an apoptotic process such as vitellogenesis and pointed out the fact that that melanins mediated indirectly to apoptosis. Melanin pigments in the frog liver at the time of hibernation were reached more than the active period after the hibernation (Purrello et al., 2001). In addition, the reason for the high amount of melanin pigments before hibernation was reported as the support of pigments by two mechanisms: reproduction or hypertrophy (Barni et al., 2002).

This study was aimed to the morphological evaluation of the histological changes that occurred before and after reproduction of the liver of male and female edible water frog Pelophylax ridibundus (Pallas, 1771) which has economic importance. Also, knowing the changes in the histomorphological structure of the liver of this species during the reproduction period are thought to contribute significantly to the production rate in the frog culture studies.

\section{MATERIALS AND METHODS}

In this study, an edible frog ( $P$. ridibundus), which has an economic importance, was used. The adult female and male frogs used in the study were collected around Gölbaşı Lake in Kırıkhan District of Hatay in March 2015. The collected adult frogs were transferred to the frog farm established in Aydincik in plastic boxes. The adult female and male frogs were placed in breeding ponds of $6 \mathrm{~m}^{2}$. For this study, twenty four breeding male frogs, with average weight $36.63 \pm 12.84 \mathrm{~g}$ and length $69.29 \pm 9.15 \mathrm{~mm}$, and twenty four female frogs with average weight and length of $56.61 \pm 19.59 \mathrm{~g}$ and $79.54 \pm 7.07 \mathrm{~mm}$ were used. For histological studies, frogs $(n=48)$ were taken from the ponds before reproduction (March) and after reproduction (June) periods and they were brought to the research laboratory of the Faculty of Marine Sciences and Technology of Iskenderun Technical University. Then, histological samples were taken from liver tissue.
The female and male frogs were kept in ice containing containers for 30 minutes and then treated with $25 \mathrm{ml}$ chloroform spilled cottons for the competition of anesthesia procedure in the laboratory. Then, the dissection procedure was carried out and the removed liver tissues were immediately stored in $10 \%$ formalin solution. Samples were then dehydrated through a series of graded alcohols, cleared in xylene, infiltrated, and embedded into paraffin. Liver paraffin wax blocks were cut into $4 \mu \mathrm{m}$ thick sections, stained with hematoxylin and eosin (H\&E), and then they were examined under Olympus CX 41 microscope (Akiyoshi \& Inoue, 2012; Seixas Filho et al., 2013). Images were captured Olympus DP 20 digital camera. Pictures of liver parenchyma were taken the most homogeneous fields possible.

\section{RESULTS AND DISCUSSIONS}

In the liver of $P$. ridibundus is a single-layer plate and it contained hepatocytes with a multi-faceted structure and round core in the middle. Also, hepatocytes arranged in clusters and these structures were surrounded by sinusoid networks of liver cordon; portal venular, hepatic arterial and bile ducts were observed to be separated from each other by the presence of traditional. In histological observations of female frogs, the liver parenchyma was cytoplasmically intense, contained low amounts of melanin pigments and lipid droplets before reproduction (march) period (Figure 1, 2). Similarly, the livers of male frogs, liver parenchyma and hepatocytes were cytoplasmically intense, containing low amounts of melanin pigment and lipid droplets (Figure 3, 4).

The livers of female and male frogs, which completed reproduction in April and May were examined histologically in June and intense amount of melanin pigment was detected on liver parenchyma (Figures 5, 6, 7). Parallel to this, obvious changes in the shape of hepatocyte cells were observed and cytoplasmic density

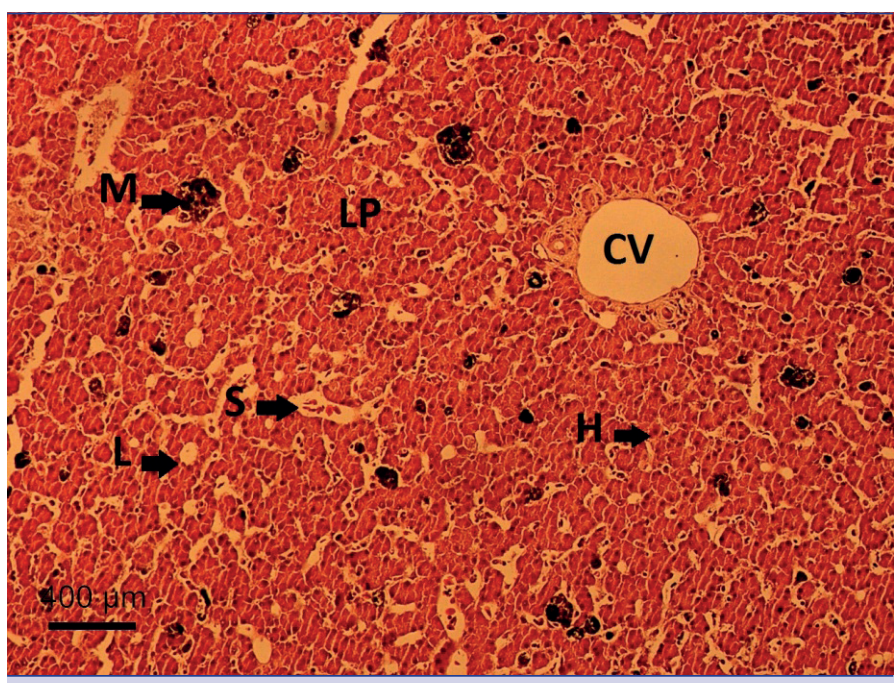

Figure 1. Low amounts of melanin pigments and lipid droplets in the liver of female frog before reproduction (H: Hepatocyte, M: Melanin, CV: Central vein, S: Sinusoid, L: Lipid, LP: Liver parenchyma. Stain: H \& E, Magnification: 10X, original) 


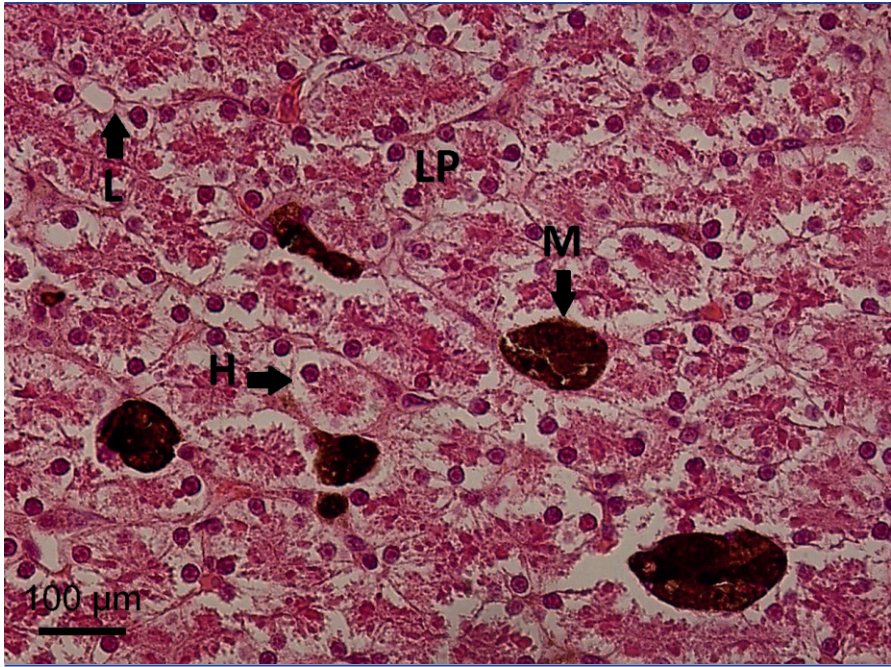

Figure 2. Low amounts of melanin pigments and lipid droplets in the liver of female frog before reproduction (H: Hepatocyte, M: Melanin, L: Lipid, LP: Liver parenchyma. Stain: $H$ \& E, Magnification: $40 X$, original).

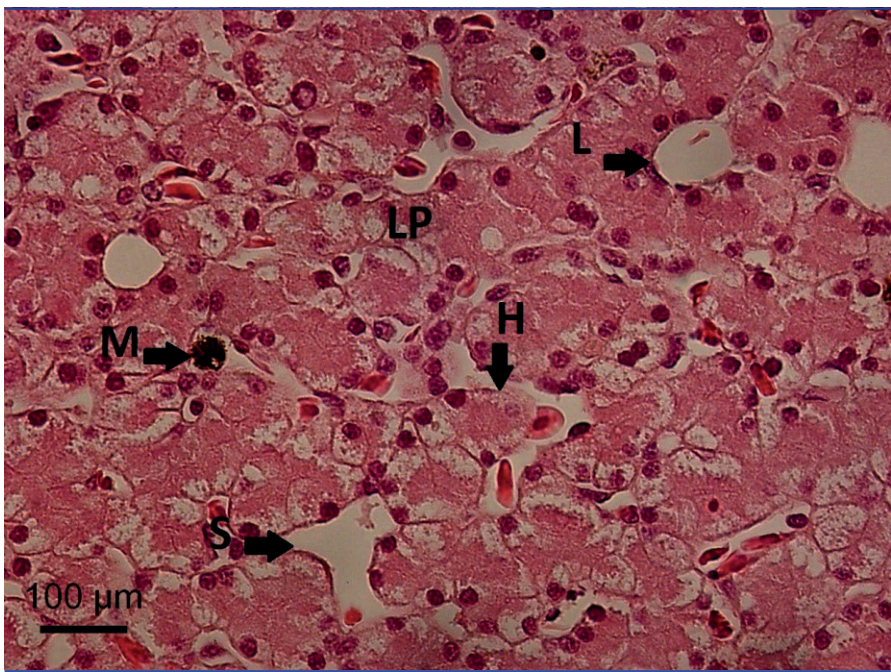

Figure 4. Low amounts of melanin pigments and lipid droplets in the liver of male frog before reproduction (H: Hepatocyte, M: Melanin, L: Lipid, LP: Liver parenchyma. Stain: $H$ \& $E$, Magnification: 40X, original).

of hepatocytes was decreased compared to pre-reproduction period in both male and female individuals (Figure 6, 8). As a result of cytoplasmic decrease, structural changes and increased melanin pigments in hepatocytes; support the idea that glycogen and liver parenchyma stored in hepatocytes are used in reproduction.

The liver is an important organ that serves as a storage for glycogen and lipids, particularly in temperate climatic conditions for hibernation species and manages the change in seasonal amounts of these two substances (Dinsmore \& Swanson 2008;

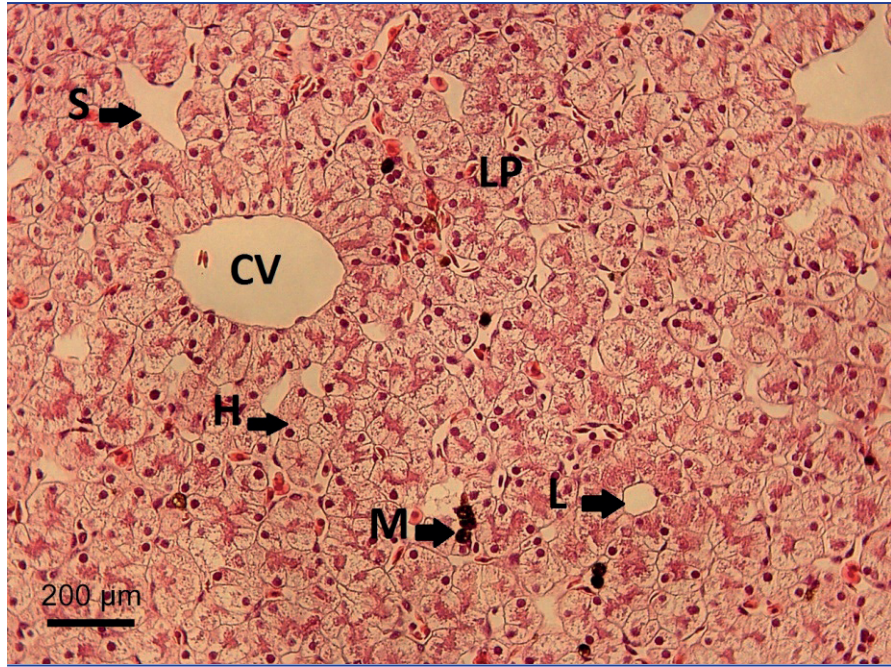

Figure 3. Low amounts of melanin pigments and lipid droplets in the liver of male frog before reproduction (H: Hepatocyte, M: Melanin, CV: Central vein, S: Sinusoid, L: Lipid, LP: Liver parenchyma. Stain: $H$ \& E, Magnification: 20X, original).

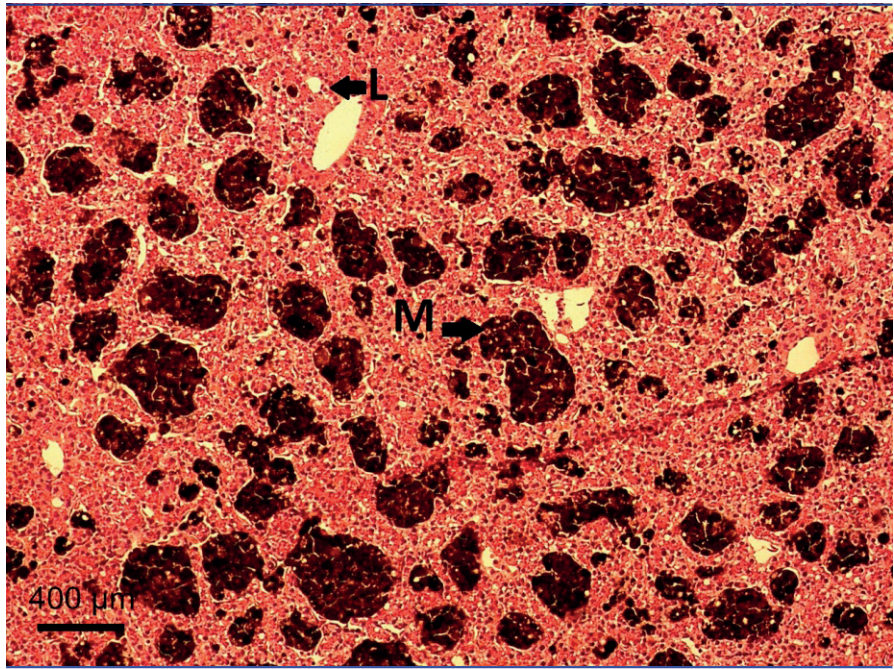

Figure 5. High amounts of melanin pigments and lipid droplets in the liver of female frog after reproduction (L: Lipid, M: Melanin. Stain: H \& E, Magnification: $10 \mathrm{X}$, original).

Fenoglio, Bernocchi \& Barni,, 1992; Pasanen \& Koskela, 1974; Singh \& Sinha, 1989). Haar and Hightower (1976) reported that Notophthalmus viridescens hepatocytes contain great amount of lipid and glycogen inclusions. Chen et al. (2011) reported in anuran that glycogen and lipid reserves increased before the reproductive period and hibernation and linked the increase between hibernation and beginning of the reproductive period with reproductive strategy. In pre-reproduction period (March), is determined that the liver parenchymal and density of hepatocytes in cytoplasm was intense for both male and female breeding frogs and melanin pigments and lipid droplets in the liver pa- 


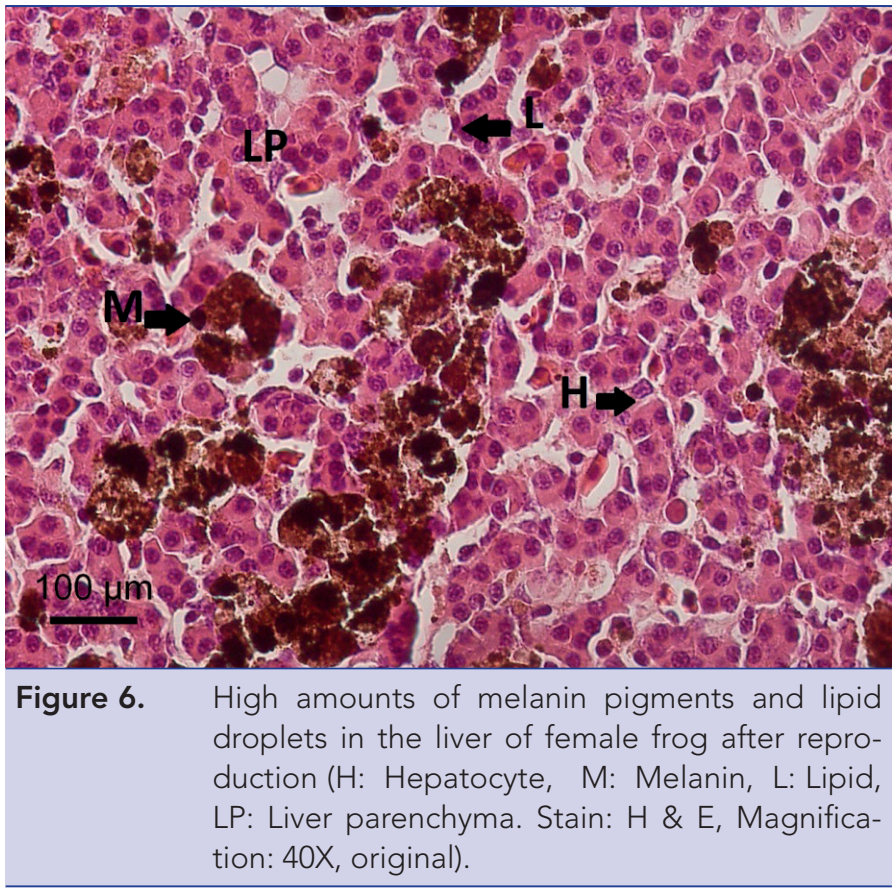

renchyma was found to be low. Therefore, it was concluded that the breeding frogs have the necessary energy reserves for reproduction and these reserves vary depending on the breeding strategy.

The concentration of glycogen and lipids is inversely related to the increase of melanin pigment in the liver cell and during the mating period of the anurans, glycogen, lipid and other substances stored in the liver were used for synthesis of egg-sperm formation related substances (Cadeddu \& Castellano 2012; Cayuela et al., 2014; Mentino et al. 2014). In another study, it was reported that degenerative changes in some liver hepatocytes may be seen after an apoptotic process such as vitellogenesis (Assisi, 1999). It is known that melanins mediate indirectly to apoptosis during vitallonegenesis (Barni et al., 2002; Purrello et al., 2001). In this study, after the reproduction of the liver of the frogs was observed histologically and detected a large number of melanin pigment on the liver parenchyma. In addition, both male and female frogs showed significant changes in the shape of hepatocyte cells and decreased cytoplasmic density of hepatocytes.

As a result, these histomorphological changes observed in the liver parenchyma; support both the idea of glycogen and lipid in the liver parenchyma or hepatocyte are used in reproduction and liver parenchyma or hepatocyte are inversely related with melanin pigment abundance. Barni et al. (1991) reported the increase in the melanin area in the liver depending on increase in hypertrophy and melanin synthesis in hibernating frogs and linked this situation inversely with glycogen storage in hepatocytes.

Mentino et al. (2017), examined the seasonal changes in the glycogen $P$. esculentus and reported that the melanin pigments in the liver reached its maximum in May and June, which may be related to reproductive activities. Similarly, in this study, melanin

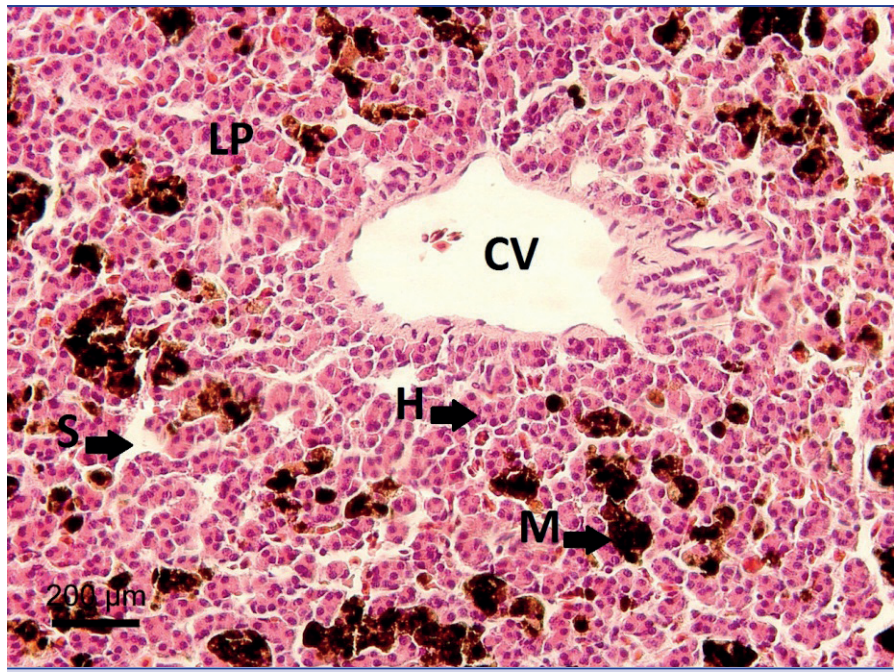

Figure 7.

High amounts of melanin pigments in the liver of male frog after reproduction (H: Hepatocyte, M: Melanin, CV: Central vein, LP: Liver parenchyma. Stain: $H \& E$, Magnification: 20X, original).

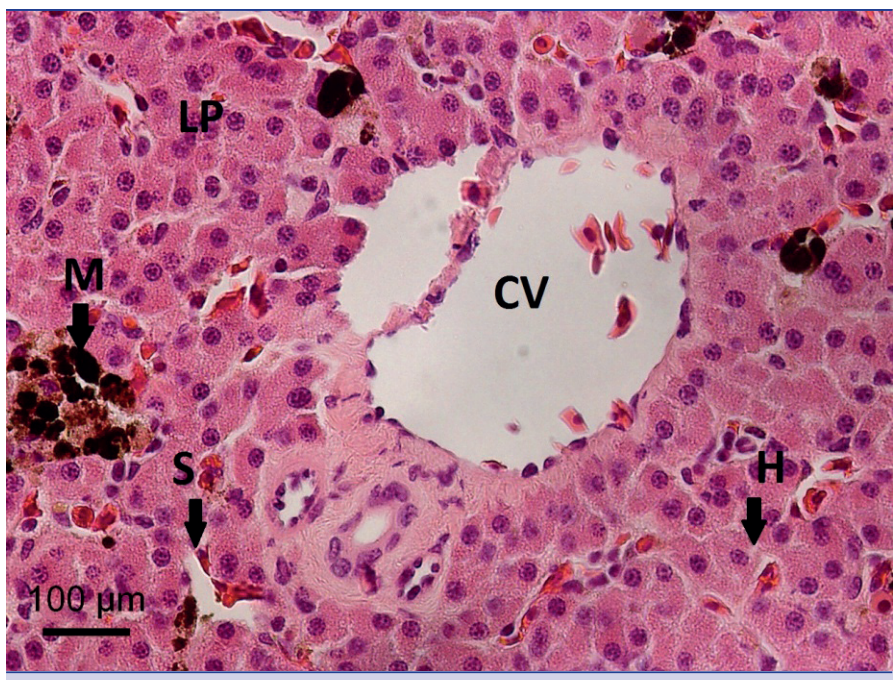

Figure 8. Cytoplasmic density of hepatocytes male frog after breeding (H: Hepatocyte, M: Melanin, CV: Central vein, LP: Liver parenchyma. Stain: H\&E, Magnification: 40X, original).

pigments in the liver were found to be a large number and the increase in melanin pigment area is thought to be related to reproduction.

\section{CONCLUSION}

As a result of cytoplasmic decrease, structural change and increase in melanin pigments on liver parenchyma after the reproduction; lipids, protein and glycogen that stored in the hepatocytes were used for reproduction. Also, this study will contribute to the production rate for frog culture by shedding light on the preparation of pellet food rations according to the metabolic energy needs of the frogs in the frog breeding period. 
Conflict of Interest: The authors have no conflicts of interest to declare

Ethics Committee Approval: This study was conducted in accordance with ethics committee procedures of animal experiments.

\section{REFERENCES}

Akiyoshi, H. \& Inoue, A. M. (2012). Comparative histological study of hepatic architecture in the three orders amphibian livers. Comparative Hepatology, 11(1), p. 1-8. [CrossRef]

Arauco, L. R. R., De Stéfani, M. V., Nakaghi, L. S. O. \& Oliveira-Bahia, V. R. L. D. (2007). Histology of kidney, liver and intestine of bullfrog tadpoles (Rana catesbeiana) fed with diets containing propolis. Ciência Rural, 37(5), 1436-1441. [CrossRef]

Assisi, L., Autuori, F., Botte, V., Farrace, M. G. \& Piacentini, M. (1999). Hormonal control of "tissue" transglutaminase induction during programmed cell death in frog liver. Experimental Cell Research, 247(2), 339-346. [CrossRef]

Bambozzi, A. C., Seixas-Filho, J. D., Thomaz, L. A., Oshiro, L. M. Y., Braga, L. G. T. \& Lima, S. L. (2004). Efeito do fotoperíodo sobre o desenvolvimento de girinos de rã-touro (Rana catesbeiana Shaw, 1802). Revista Brasileira de Zootecnia, 33(1), 1-7. [CrossRef]

Barni, S. \& Bernocchi, G., (1991). Internalization of erythrocytes into liver parenchymal cells in naturally hibernating frogs (Rana esculenta L.). J. Exp. Zool., 258(2), 143-150. [CrossRef]

Barni, S., Bertone, V., Croce, A. C., Bottiroli, G., Bernini, F. \& Gerzeli, G. (1999). Increase in liver pigmentation during natural hibernation in some amphibians. The Journal of Anatomy, 195(1), 19-25. [CrossRef]

Barni, S., Vaccarone, R., Bertone, V., Fraschini, A., Bernini, F. \& Fenoglio, C. (2002). Mechanisms of changes to the liver pigmentary component during the annual cycle (activity and hibernation) of Rana esculenta. L. Journal of Anatomy, 200(2), 185-194. [CrossRef]

Cadeddu, G. \& Castellano, S. (2012). Factors affecting variation in the reproductive investment of female treefrogs, Hyla intermedia. Zoology, 115(6), 372-378. [CrossRef]

Cayuela, H., Besnard, A., Bonnaire, E., Perret, H., Rivoalen, J., Miaud, C. \& Joly, P. (2014). To breed or not to breed: past reproductive status and environmental cues drive current breeding decisions in a longlived amphibian. Oecologia, 176(1), 107-116. [CrossRef]

Chen, W., Zhang, L-X. \& Lu, X. (2011). Higher pre-hibernation energy storage in anurans from cold environments: A case study on a temperate frog Rana chensinensis along a broad latitudinal and altitudinal gradients. Annales Zoologici Fennici, 48(4), 214-220. [CrossRef]

Crawshaw, G.J. \& Weinkle, T.K. (2000). Clinical and pathological aspects of the amphibian liver. Seminars in Avian and Exotic Pet Medicine, 9(3), 165-173. [CrossRef]
Dinsmore, S. C. \& Swanson, D. L. (2008). Temporal patterns of tissue glycogen, glucose, and glycogen phosphorylase activity prior to hibernation in freeze-tolerant chorus frogs, Pseudacris triseriata. Canadian Journal of Zoology, 86(10), 1095-1100. [CrossRef]

Fenoglio, C., Bernocchi, G. \& Barni, S. (1992). Frog hepatocyte modifications induced by seasonal variations: a morphological and cytochemical study. Tissue and Cell, 24(1), 17-29. [CrossRef]

Gernhofer, M., Pawet, M., Schramm, M., Müller, E. \& Triebskorn, R. (2001). Ultrastructural Biomarkers as Tools to Characterize the Health Status of Fish in Contaminated Streams. Journal of Aquatic Ecosystem Stress and Recovery, 8, 241-226. [CrossRef]

Haar, J. L. \& Hightower, J.A.A. (1976). Light and electron microscopic investigation of the hepatic parenchyma of the adult newt, Notophthalmus viridescens. The Anatomical Record, 185(3), 313-323. [CrossRef]

Hipolito, M., Leme, M. C. M. \& Bach, E. E. (2001). Lesões anátomohistopatológicas em rãs-touro (Rana catesbeiana Shaw, 1802) associadas à deterioração da ração. Arquivos do Instituto de Biologia, 68(1), 111-114.

Hipolito, M., Martins, A. M. C. R. P. F. \& Bach, E. E. (2004). Aspectos bioquímicos em fígado de rãs-touro (Rana catesbeiana Shaw, 1802) sadias e doentes. Arquivos do Instituto Biológico, 71(2), 147-153.

Mentino, D., Mastrodonato, M., Rossi, R. \& Scillitani, G., (2014). Histochemical and structural characterization of egg extra-cellular matrix in bufonid toads, Bufo bufo and Bufotes balearicus: Molecular diversity versus morphological uniformity. Microscopy Research and Technique, 77(11), 910-917. [CrossRef]

Mentino, D., Scillitani, G., Marra, M. \& Mastrodonato, M. (2017). Seasonal changes in the liver of a non-hibernating population of water frogs, Pelophylax kl. esculentus (Anura: Ranidae). The European Zoological Journal, 84(1), 525-535. [CrossRef]

Pasanen, S. \& Koskela, P. (1974). Seasonal and age variation in the metabolism of the common frog, Rana temporaria $L$. in northern Finland. Comparative Biochemistry and Physiology Part A: Physiology, 47(2), 635-654. [CrossRef]

Purrello, M., Scalia, M., Corsaro, C., Di Pietro, C., Piro, S. \& Sichel, G. (2001). Melanosynthesis, differentiation, and apoptosis in Kupffer cells from Rana esculenta. Pigment cell research, 14(2), 126-131. [CrossRef]

Seixas Filho, J. T., Hipólito, M., Pereira, M. M., Martins, A. M. C. R. P. F., Rodrigues, E. and Mello, S.C.R.P., (2013). Liver histopathological changes in breeding bullfrogs. Acta Scientiarium Animal Science, 35:461-465. [CrossRef]

Singh, R. P. \& Sinha, R. C. (1989). Seasonal changes in energy reserves in the common frog, Rana tigrina. The Japanese Journal of Physiology, 39(6), 969-973. [CrossRef]

Wester, P. W. \& Canton, J. H. (1991). The usefulness of histopathology in aquatic toxicity studies. Comparative Biochemistry and Physiology. C, Comparative Pharmacology and Toxicology, 100(1-2), 115-117. [CrossRef] 